\title{
The HISTMAG database: combining historical, archaeomagnetic and volcanic data
}

\author{
Patrick Arneitz, ${ }^{1}$ Roman Leonhardt, ${ }^{1}$ Elisabeth Schnepp, ${ }^{2}$ Balázs Heilig, ${ }^{3}$ \\ Franziska Mayrhofer, ${ }^{1,4}$ Peter Kovacs, ${ }^{3}$ Pavel Hejda, ${ }^{5}$ Fridrich Valach, ${ }^{6}$ \\ Gergely Vadasz, ${ }^{3}$ Christa Hammerl, ${ }^{1}$ Ramon Egli, ${ }^{1}$ Karl Fabian ${ }^{7}$ and Niko Kompein ${ }^{1}$ \\ ${ }^{1}$ ZAMG, 1190 Vienna, Austria.E-mail: patrick.arneitz@zamg.ac.at \\ ${ }^{2}$ Palaeomagnetic Laboratory Gams, 8130 Frohnleiten, Austria \\ ${ }^{3}$ Geological and Geophysical Institute of Hungary, 8237 Tihany, Hungary \\ ${ }^{4}$ Department for Geodynamics and Sedimentology, University of Vienna, 1090 Vienna, Austria \\ ${ }^{5}$ Institute of Geophysics, Czech Academy of Sciences, Praha 4, Czech Republic \\ ${ }^{6}$ Geomagnetic Observatory, Earth Science Institute, Slovak Academy of Sciences, 94701 Hurbanovo \\ ${ }^{7}$ Geological Survey of Norway, 7491 Trondheim, Norway
}

Accepted 2017 June 6. Received 2017 May 23; in original form 2017 February 10

\begin{abstract}
S UMMAR Y
Records of the past geomagnetic field can be divided into two main categories. These are instrumental historical observations on the one hand, and field estimates based on the magnetization acquired by rocks, sediments and archaeological artefacts on the other hand. In this paper, a new database combining historical, archaeomagnetic and volcanic records is presented. HISTMAG is a relational database, implemented in MySQL, and can be accessed via a web-based interface (http://www.conrad-observatory.at/zamg/index.php/data-en/histmag-database). It combines available global historical data compilations covering the last $\sim 500 \mathrm{yr}$ as well as archaeomagnetic and volcanic data collections from the last 50000 yr. Furthermore, new historical and archaeomagnetic records, mainly from central Europe, have been acquired. In total, 190427 records are currently available in the HISTMAG database, whereby the majority is related to historical declination measurements (155 525). The original database structure was complemented by new fields, which allow for a detailed description of the different data types. A user-comment function provides the possibility for a scientific discussion about individual records. Therefore, HISTMAG database supports thorough reliability and uncertainty assessments of the widely different data sets, which are an essential basis for geomagnetic field reconstructions. A database analysis revealed systematic offset for declination records derived from compass roses on historical geographical maps through comparison with other historical records, while maps created for mining activities represent a reliable source.
\end{abstract}

Key words: Europe; Archaeomagnetism; Magnetic field variations through time; Palaeomagnetism.

\section{INTRODUCTION}

Two data types reveal details about the past geomagnetic field. On the one hand, the remanent magnetization of rocks, sediments and archaeological artefacts can be investigated to reconstruct the direction and intensity of the geomagnetic field (indirect records). On the other hand, geomagnetism is one of the longest established sciences in human history and, therefore, historical (direct) field readings have been performed during the last centuries.

In ancient times, the attractive force of natural magnets (lodestone) on iron was already known and described by natural philosophers like Thales of Miletus (e.g. Courtillot \& Le Mouël 2007). Its directive property was first discovered in China and the lodestone was used to magnetize iron to design first 'floating compasses' (iron placed on cork floating on the water) in the first centuries AD (e.g. Balmer 1956). In later developments, the needle was suspended on a fibre as described by Shen Kua around 1088 AD, who also noted that the needle did not exactly point to the south, but deviated slightly to the east (see e.g. Kono 2007, and references therein). Older observations of magnetic declination from the medieval China were compiled by Smith \& Needham (1967). The oldest of these measurements was performed by the Buddhist astronomer I-Hsing around 720 AD (Needham 1962).

The earliest mentions of the compass in Europe occur around 1187 AD (e.g. Chapman \& Bartels 1962): Alexander Neckham wrote about the common use of the magnetic needle to indicate 
north for mariners and described a compass, where a needle was placed on a pivot. A more detailed design of a pivoted compass as well as the concept of magnetic poles were given by Petrus Peregrinus (e.g. Courtillot \& Le Mouël 2007) in his famous 'Epistola de Magnete' in 1269. Nevertheless, declination was unknown during these times, which is reflected, for example, by the distortion and rotation of old portolan charts (navigational maps based on compass directions), which can be used to reconstruct historical declination values (Yilmaz et al. 2010). The discovery of declination in Europe is attributed to sundial designers of the 15th century (e.g. Balmer 1956; Chapman \& Bartels 1962), who marked the value on the compass attached to the sundial to guarantee an accurate orientation. The earliest known value was recorded by Georg Peuerbach in 1451 (Zinner 1939). However, this knowledge was initially not widely distributed and the deviation of the needle from geographic north was explained by imperfections of the instruments and/or the lodestone used to magnetize the needle (Balmer 1956).

The slant of the magnetic needle was first described by Georg Hartmann in a letter from 1544, while Robert Norman performed the first specific measurement of inclination with the dip circle in 1576 (e.g. Courtillot \& Le Mouël 2007). This discovery formed the basis for Gilbert's experiments, which were summarized in his famous publication 'De Magnete' from 1600. Gilbert investigated deflections of the needle caused by a spherical magnet (called 'terella') - a similar one had been used by Petrus Peregrinus for his experiments - and concluded that the Earth itself is a magnetic body (e.g. Kono 2007).

As soon as the temporal change of declination ('secular variation') was observed by Gellibrand in 1634 (e.g. Chapman \& Bartels 1962), monitoring of the geomagnetic field started at individual locations like London (Malin \& Bullard 1981) or Paris (Alexandrescu et al. 1996). The spatial variation of geomagnetic directions was investigated during several marine voyages, which led to the first isogonic chart of the Atlantic by Halley (1701). During the late 18 th and in the beginning of the 19th century, the first iron-free observatories were constructed (e.g. Chapman \& Bartels 1962), while the systematic observation of all geomagnetic field components on a global scale is marked by the initiation of the 'Göttingen Magnetic Union' by Gauss and Weber in 1830s. Gauss (1833) complemented geomagnetic measurements with his method for absolute field intensity determination; earlier - from the end of the 18th century - relative values had been derived from the oscillation period of the needle displaced from its rest position (e.g. von Humboldt 1814-1829).

In the middle of the 19th century, first investigations of the natural remanent magnetization of rocks were performed, which enabled a look back into the geomagnetic past far beyond the historical period. Around 1850 Delesse and Melloni found that some rocks have a magnetization parallel to the Earth's magnetic field (e.g. Kono 2007). Folgheraiter (1899) extended the studies on baked archaeological materials like pottery and bricks. Ongoing investigations enabled great scientific progress like the discovery of field reversals and its influence on the theory of plate tectonics. Besides these remarkable contributions, the Thellier method (Thellier \& Thellier 1959) — based on works by Folgheraiter (1899) and Koenigsberger (1936) - for palaeointensity measurements represented a landmark for studies of palaeosecular variations. Since then, a variety of different palaeointensity protocols as well as quality checks and corrections (for anisotropy, alteration, cooling rate dependence) have emerged. The reader is referred to, for example, Brown et al. (2015a) or Paterson et al. (2014), and references therein for a detailed discussion.
In the last decades, great efforts were made to collect archaeoand palaeomagnetic records (e.g. Korte et al. 2005; Donadini et al. 2006; Genevey et al. 2008; Korhonen et al. 2008). The most up to date compilation is provided by the GEOMAGIA50.v3 database (Brown et al. 2015a,b). On the other hand, one global data set of historical records is available (Jonkers et al. 2003), while other studies focused on restricted areas (e.g. Korte et al. 2009) or scientific expeditions (e.g. Hansen \& Aspaas 2005). Nevertheless, a comprehensive approach to provide these different collections within one openly accessible database with inclusion of essential metadata describing the historical measurements, is absent up to now.

In this paper, we present a combined database integrating historical as well as archaeomagnetic and volcanic records. The structure of HISTMAG database is strongly aligned with those of GEOMAGIA50.v3 (Brown et al. 2015a, http://geomagia.gfz-potsdam.de/, last accessed February 2017) and the compilation by Jonkers et al. (2003), which contribute the major part to the global data collection. Therefore, we will focus on new database fields describing the records as well as new features of database handling in Section 2, while the technical details and the common metadata framework is presented in the associated manual of HISTMAG database (Supplementary Materials A). In Section 3, the different data sets are described. In this section, we put strong emphasis on the newly acquired historical and archaeomagnetic data sets from central Europe. The collected metadata allow for an analysis of the reliability as well as accuracy of historical records (Section 4). Section 5 gives a summary of the database and a future outlook.

\section{DATABASE STRUCTURE}

HISTMAG is a dynamic web-based database accessible online at http://www.conrad-observatory.at/zamg/index.php/data-en/histmag -database (upon successful registration at the website). It is based on the LAMP (Linux, Apache, MySQL, PHP) model. The user can access HISTMAG via a web-based interface and data are stored in the relational database management system MySQL. The Apache HTTP web server is used to process users' requests. PHP is the server-side scripting language used to make these requests readable for the MySQL database on the one hand, and to transform the output in form of HTML tables and output files on the other hand. The relational structure of the database (Fig. 1) allows to join different tables containing different information for each record. While the data table contains the majority of the records' information, additional tables were created in order to store related meta information comprising several fields (sites, literature), to enable the assignment of more than one value to one field in data (dating, refs) or to allow for special user needs and interaction (search, discussion).

HISTMAG database is strongly influenced by the main collections regarding historical data from the last $\sim 500 \mathrm{yr}$ (Jonkers et al. 2003) and archaeomagnetic and volcanic records (Brown et al. 2015a) covering the last $50 \mathrm{kyr}$. Therefore, most fields have been adopted from the two compilations. Furthermore, the query interface offers similar options as GEOMAGIA50.v3. While the HISTMAG manual (Supplementary Materials A) contains all details of the fields describing the records as well as the web interface, we only want to briefly present noteworthy modifications of the structure below. Historical as well as archaeomagnetic and volcanic records are described by fields, which can be generally summarized in four 


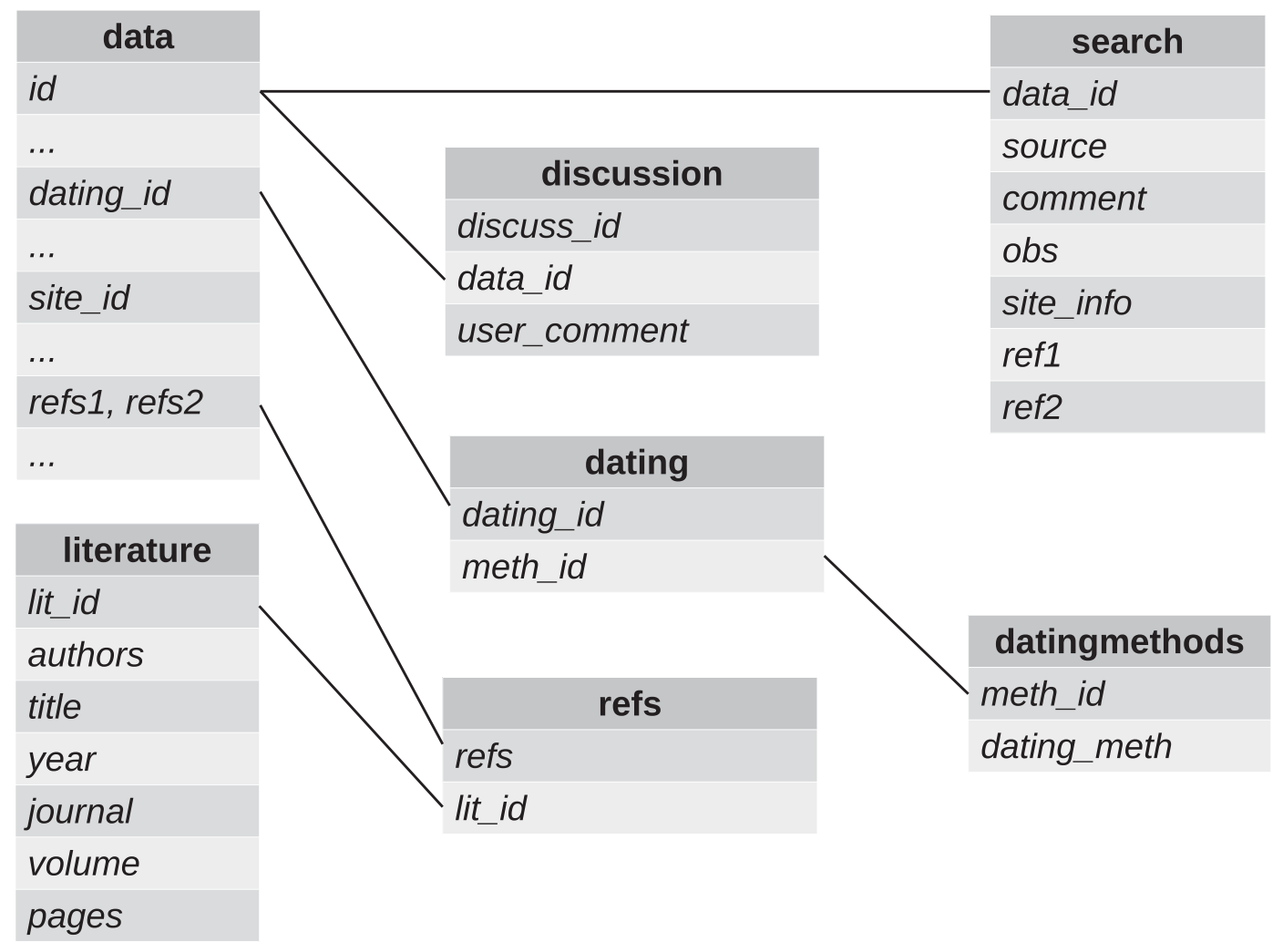

Figure 1. Schematic overview of tables and relations in the MySQL database.

categories:

(i) Time

(ii) Location

(iii) Measurement

(iv) Reference

The age of the record is complemented by information of its uncertainty and the dating procedure. We have introduced a set of additional fields (seq, prev, next, equal) which allows for the identification of the records' location within a stratigraphy (see Section 3.2.2), which provides further temporal information. The local time of the historical records - typically for observatories performing several measurements per day - is given according to the original publications (hour). The extra information of the radio carbon results table on $\mathrm{C} 14$ ages (e.g. uncalibrated $\mathrm{C} 14$ age) from GEOMAGIA50.v3 (Brown et al. 2015a) has not been incorporated. The records' geographical position is described by coordinates (latitude lat and longitude lon) and, when available, the place name (site, location, country).

Metadata describing palaeomagnetic measurements have been adopted from Brown et al. (2015a). Minor changes, mainly related to the field names, are documented in the HISTMAG manual (Supplementary Materials A). For historical measurements, several new fields are presented. If available, the observer $(o b s)$, the used instrument (e.g. decl_inst) and the method (e.g. decl_meth) are listed. The latter field allows to specify whether the presented magnetic value was derived from a direct measurement, was reconstructed (e.g. from mining adit directions), or represents the mean of a measurements series (e.g. annual mean). For intensity values, the code scheme by Jonkers et al. (2003) was adopted to distinguish between absolute and relative measurements (first letter of inten_code: 'A' or ' $R$ ') and measurements of the total or horizontal intensity (second letter of inten_code: ' $\mathrm{T}$ ' or ' $\mathrm{H}$ '). It has to be noted, that all historical intensities have been converted to nanotesla (except for some old relative intensity measurements, see Section 3.1.1). For this purpose, the third letter of inten_code revealing details of the original intensity unit/scale and conversion factor cal (according to tables 3 and 4 in Jonkers et al. 2003) were used.

The 'Reference category' comprises literature as well as remarks on records extracted from the original documents or the processors (comment). Additionally, the source field is used to group historical field readings for different applications in the past (e.g. data from mining activities or from sundials) or defines the material investigated in archaeo- and palaeomagnetic studies. The comp_id field is used to identify subsets of the compilation by Jonkers et al. (2003) as well as records extracted from GEOMAGIA50.v3 database (Brown et al. 2015a). The possibility to flag records was implemented for three reasons. (1) Unreliable values can be marked (e.g. displaced archaeological features). (2) Different data sets might contain the same records. If such duplicates were detected, the record with less or wrong metadata was flagged (see Section 3.3). (3) The flag 'modelling' is aimed to facilitate data selection for geomagnetic modelling purposes. Therefore, records missing essential information on age, longitude, latitude or without geomagnetic measurement values can be automatically excluded from the query. Furthermore, series of single observations (e.g. daily measurements) are excluded and instead mean values (e.g. annual) are available, which are sufficient for the temporal resolution of global geomagnetic field modelling. For a few newly acquired historical data sets additional mean values were calculated (e.g. for all mining adit directions of one mining site at the same year) to support the above-mentioned flagging approach. These values can be identified via the comment field entry 'histmag calculation'.

Finally, we want to present two new key features of HISTMAG database. First, users have the possibility to comment each record (field user_commment in table discussion). This offers the 
Table 1. Number of records included in the HISTMAG database: the total number $n_{\text {records }}$ as well as individual declination $\left(n_{D}\right)$, inclination $\left(n_{I}\right)$ and intensity records $\left(n_{F}\right)$ for different data sets.

\begin{tabular}{lrrrr}
\hline Data set & $n_{\text {records }}$ & \multicolumn{1}{c}{$n_{D}$} & $n_{I}$ & $n_{F}$ \\
\hline Historical & & & & \\
Jonkers et al. (2003) & 177067 & 151560 & 19525 & 16201 \\
Korte et al. (2009) & 615 & 615 & 26 & 0 \\
This study & 3545 & 3350 & 628 & 626 \\
Archaeomagnetic and volcanic & & & & \\
Brown et al. (2015a) & 9017 & 3847 & 5529 & 5159 \\
This study & 183 & 57 & 112 & 114 \\
Total & 190427 & 159429 & 25820 & 22100 \\
\hline
\end{tabular}

opportunity for a fruitful discussion on the different data enabling a better assessment of the quality and the reliability of the records. Secondly, we have implemented a 'Keyword Query', which scans metadata for matches. This query type is realized by a separate table (search) with full-text index on the fields describing the source, location, literature, observer and comment of the records. The reader is referred to the HISTMAG manual (Supplementary Materials A) to see illustrative examples of the user-comment function and the 'Keyword Query'.

\section{DATA}

The current version of HISTMAG database comprises 190427 records of the past geomagnetic field (Table 1) on the global scale. It has to be pointed out that the majority of records comes from pure historical declination measurements without inclination or intensity information $(\sim 140000)$ due to the application of the magnetic compass in navigation and orientation. The main focus of this studybeside the proper preparation of the database structure-was the acquisition of new records. Major focus was set on central Europe, where our team had the best access to archives and documents as well as archaeological sites, respectively (Fig. 2). In the following subsections, details on the historical as well as archaeomagnetic and volcanic collections are presented.

\subsection{Historical records}

\subsubsection{Published collections}

The compilation by Jonkers et al. (2003) is the centrepiece of the global historical data collection. It contributes $\sim 177000$ records, from which the majority was measured on ship voyages. About 17000 from these records represent land sightings and do not have any information on the geomagnetic field components. All data were integrated into the database and can be retrieved via source value 'Jonkers et al. (2003)' in the online query form. Different data sets or voyages within the collection are identified by the comp_id ' $\mathrm{JX}$ ', where $\mathrm{X}$ stands for the idcode used by Jonkers et al. (2003). Longitudes (as well as latitudes) are given in decimal numbers relative to Greenwich and were calculated using the list of different prime meridians provided by Jonkers et al. (2003). In one case ('J4172'), the missing prime meridian for Concepción, Chile, was added (de Ulloa \& Schwabe 1751). For two records from set 'J3318', however, no longitudes could be determined because the prime meridian could not be reconstructed. A few typos associated with the date of the records have been identified upon data import and corrected (noted in the comment field). While all declination and inclination data have been transformed (from degrees and minutes) to decimal numbers, intensity values were converted (from different scales/units), when necessary and possible, to nanotesla. This conversion is based on the field inten_code and the conversion factor cal (see tables 3 and 4 in Jonkers et al. 2003). For the oldest relative intensity measurements in 1791-1794 by De Rossel ('J3500') and in 1799 by Humboldt ('J4484'), however, no adequate conversion factor was given. In these cases, relative values of intensity are reported in the records' comment field.

About 1200 intensity records exist in the database, which are termed as absolute, but - starting with the year 1816 - had been measured before Gauss (1833) presented a method to determine the absolute (horizontal) intensity. About 700 values come from collections provided by Edward Sabine and are given in British units (inten_code: 'ATB'). It has to be pointed out that, for example, early observations in 1818-1820 were originally relative measurements (e.g. Sabine 1838) and later converted to British units in the course of compiling these values (e.g. Sabine 1872). The other $\sim 500$ records represent horizontal intensities in nanotesla (inten_code: 'AHN') and mainly come from surveys conducted on Russian territory (e.g. Veinberg 1929-1933). Here, also belated conversions from relative to absolute measure have to be assumed. Since the exact transition from relative to absolute measurements - which can be expected to differ for different observers, regions, etc.-is not assignable without detailed study of the original sources, the term absolute (within the inten_code) is preserved in the database for above discussed records. The user-comment function, however, provides the possibility to identify original relative measurements.

Jonkers et al. (2003) reported that for certain historical compilations (Stevin 1599; Kircher 1654; Wright 1657) distinct date information is missing. The respective publication year has been ascribed to these observations, which, however, could have been performed well before that time. Therefore, identified records are flagged (as unreliable) in the database.

Korte et al. (2009) provided a historical data collection in the area around Southern Germany and examined several untouched sources - e.g. sundials (Fig. 3) or mining activities (Fig. 4) - for the investigation of temporal geomagnetic field changes. The records were extracted from the supporting information of Korte et al. (2009). Additional meta information, if available, has been added from cited primary sources. During this investigation it turned out that certain records from Schreyer (1886) for Berlin, Munich, Regensburg and Prague do not represent historical declination values for the mentioned locations; in fact, these records are interpolated declination values for Freiberg from the given locations and, consequently, they were not integrated into the database.

\subsubsection{This study}

Previous investigations of historical geomagnetic field measurements pointed out several potential sources, which we examined in central Europe (Fig. 2a). We collected all available metadata to enable an uncertainty assessment of the different records (Section 4). Furthermore, several records from recent papers were integrated into the database. Below, the different sources as well resulting data sets are discussed.

Besides sundials, mining activities are one of the oldest sources of geomagnetic measurements in central Europe (Fig. 4). Since $\sim 13$ th/14th century, the compass has been used for the orientation and mapping of mine adits (Ludwig \& Schmidtchen 1997). Christian Doppler realized the potential of this source for the reconstruction of historical declination values and instructed mining areas in the Imperial and Royal Empire to investigate old surveyor 
(a)
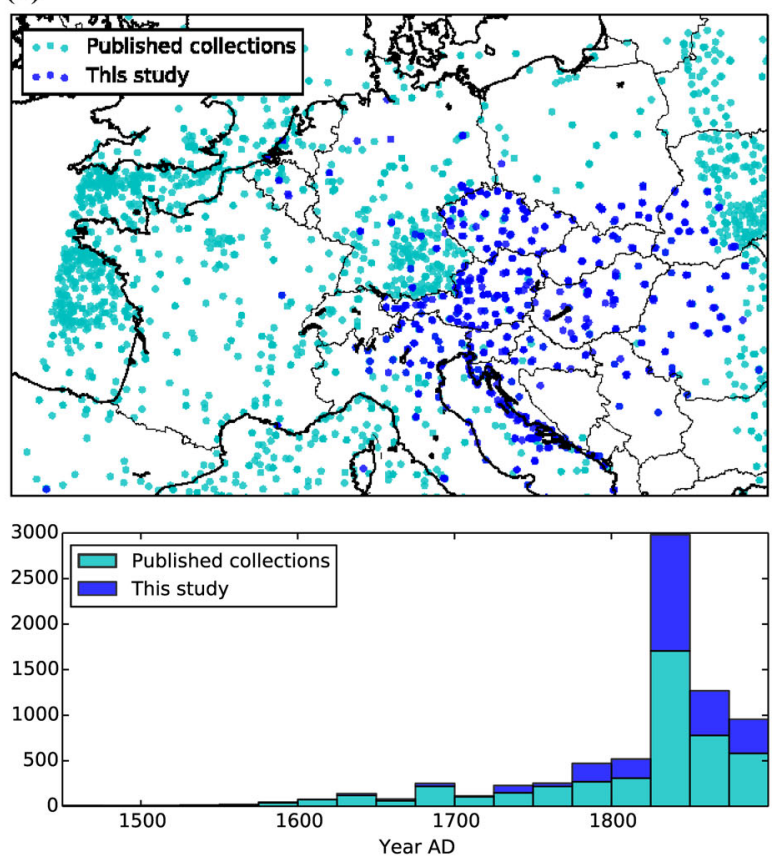

(b)
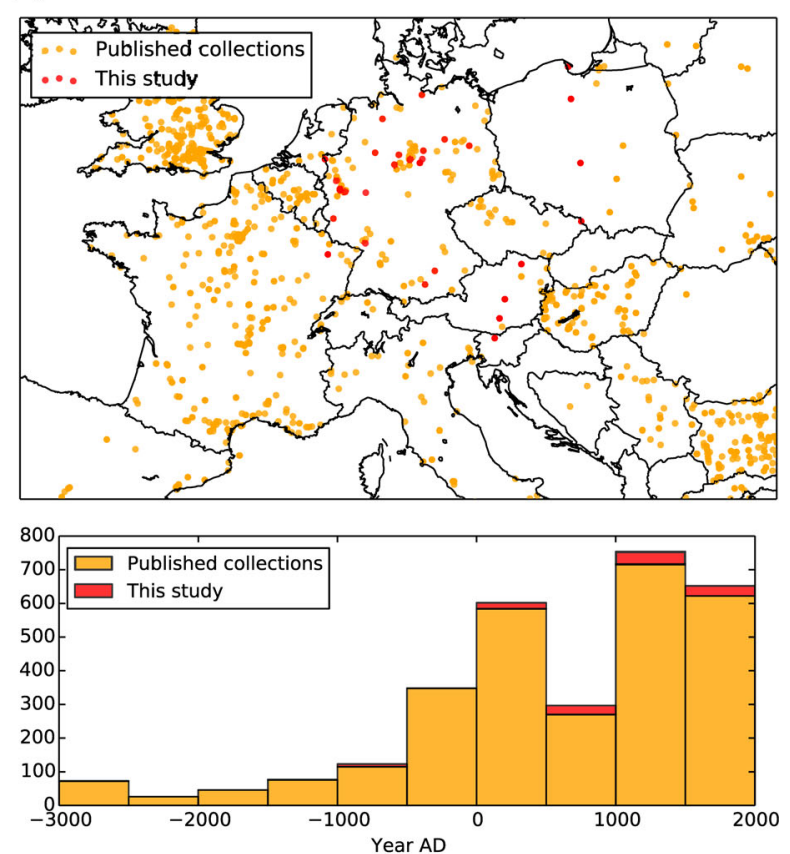

Figure 2. Spatial (top) and temporal (bottom) distribution of (a) historical and (b) archaeomagnetic and volcanic records from central Europe.

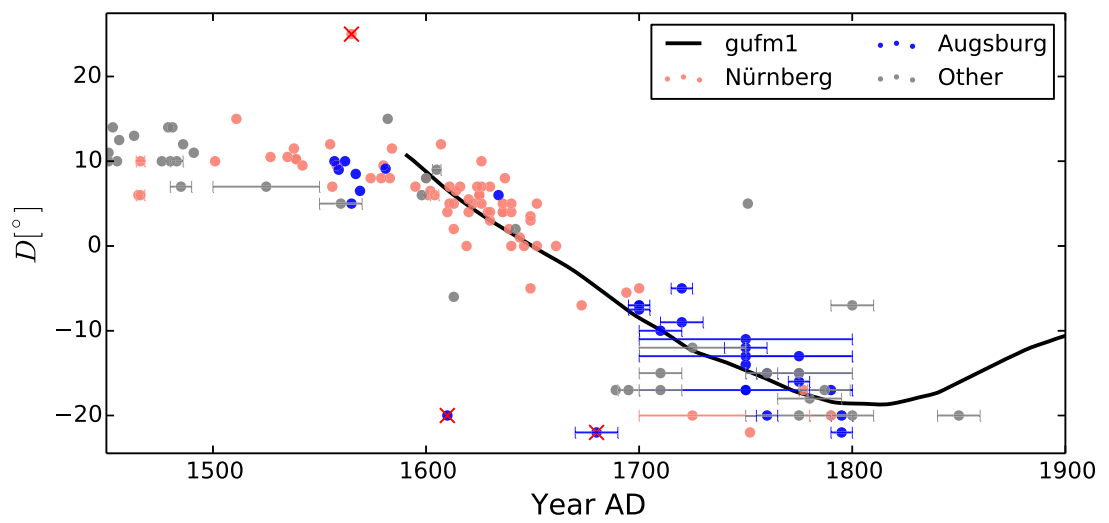

Figure 3. Declination values marked on compasses attached to sundials from central Europe (Korte et al. 2009). The declination curve for Munich, calculated from the gufm1 model (Jackson et al. 2000), is shown for comparison. Outliers for the time-series of Nürnberg and Augsburg are marked with red crosses.

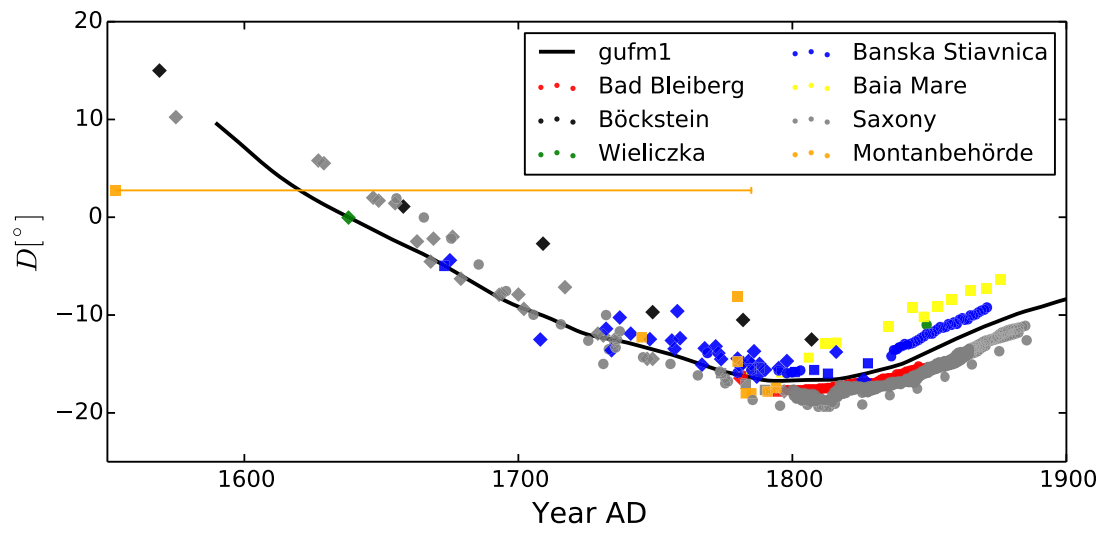

Figure 4. Declination values collected from mining activities. Direct observations are given by the circles, while records reconstructed from old adit directions are depicted by the diamonds and records noted on mining maps by the squares. The declination curve for Vienna, calculated from the gufm 1 model (Jackson et al. 2000), is shown for comparison. 


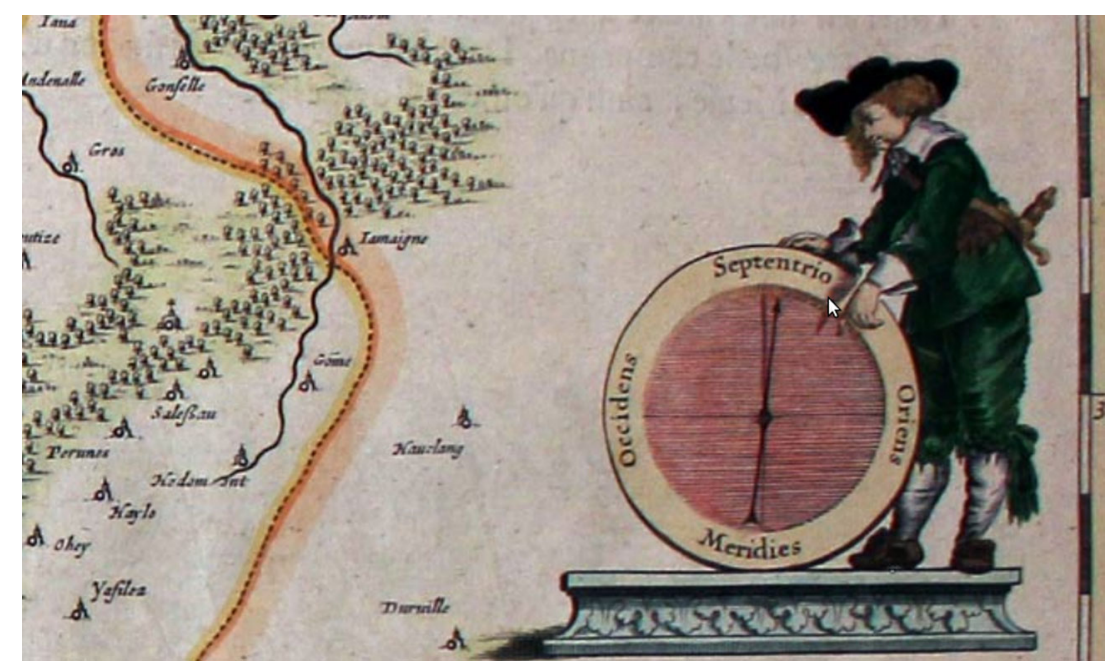

Figure 5. Compass rose on a historical topographic map (1579 AD) from the Austrian State Archives (AIII3 Blatt 37 ).

maps and books (Doppler 1850). These old documents contained adit directions from previous centuries, which could be compared to current directions. In this way, declination time-series for mining areas in Böckstein, Wieliczka and Bad Bleiberg were derived. For the latter location, additional direct declination measurements were performed from 1782 to 1846. Doppler (1851) also provided the impetus for the collection of declination values from the mining area Freiberg, Saxony, where the compass had been in use in mining activities at least since the 16th century. Schreyer (1886) took up this idea for his collection of geomagnetic observations in Saxony and compiled a comprehensive time-series for several mining areas (e.g. Freiberg and Clausthal). Korte et al. (2009) have already compiled most records from Schreyer (1886). While they focused on decennial and annual means, we provide further single measurement results as well as meta information on the origin of the records from Saxony (e.g. if declination was directly measured or reconstructed from adit directions). The most famous mining site in the Kingdom of Hungary was Selmecz, also called Schemnitz (now Banská Štiavnica, Slovakia), where Christian Doppler was professor at the mining university Berg- und Forstakademie Schemnitz (In Slovak: Banícka a lesnícka akadémia, Banská Štiavnica) from 1847 to 1849. He instructed Markscheidsadjunct Pál Balás with the collection of old declination data, whereby the comparison of adit directions was the primary source for earlier centuries (Balás 1850). Direct measurements were sporadically performed during the 18th century, and more regularly during the 19th century. Furthermore, we could acquire five maps in the map collection of Slovenský banský archív v Banskej Štiavnici, on which old declination values had been written down. Similar findings could be made for Nagybánya (now Baia Mare, Romania) (Steiner 1923) as well as in the map archive of the Austrian Montanbehörde. To summarize, mining activities offer a valuable amount of historical declination data from three different sources: (1) adit directions, (2) direct observations and (3) mining maps. The temporal evolution of declination extracted from these sources is depicted in Fig. 4.

The knowledge of declination was also very important for the creation of topographic maps at the beginning of the modern era. Philipp Appian already considered the magnetic declination during his mapping survey for his 'Bayern-Karte' in the middle of the 16th century (Lindgren 2013). On old maps one can occasionally find compass roses, which - in several cases - show the magnetic needle pointing to a different direction than geographic North 'Septentrio' (e.g. Fig. 5). This can be interpreted as a measure for the magnetic declination for the period and region the map is related to. However, in several cases the question arises, if these compass roses should be rather seen as a decorative accessories than a scientifically documented record. Only in a few cases, the declination value is written down on the map increasing its credibility. We have compiled 48 declination values from historical maps by investigating the Austrian State Archives, the Hungarian National Archive, the Sopron Archive as well as online databases. For maps of larger areas (e.g. of one country), coordinates were estimated from the centre of the displayed region.

Mapping campaigns for the army are another valuable source for historical magnetic measurements. Luigi Ferdinando Marsigli worked as a military engineer on mapping for the Imperial army in 1696. During the survey, he recorded declination values with four compasses and published the results of compass 4 (Marsigli 1700). The observations of all four compasses could be found in Bologna (Marsigli 1696) and we calculated weighted means of results from compasses 2 (weight 1) and 4 (weight 2), as compasses 1 and 3 seemed to be unreliable.

During the 18th century, a steady increase in number of declination measurements on the continent can be constituted. Isolated records can be found, for example, in Mikoviny (1732, 1735). Declination observations were often performed in combination with other scientific measurements like astronomical ones as in case of the observatory Altdorf (Müller et al. 1723). Jesuit Father and astronomer Maximillian Hell travelled in 1768 to Vardø, Norway, to observe the transit of Venus. Hansen \& Aspaas (2005) provided a comprehensive summary of his journey comprising time-series of declination at Vardøfrom 1769 April-June and observations on his way back to Copenhagen. However, artificial iron objects (oven, quadrant) as well as magnetic storm(s) disturbed his measurements (see Section 4).

The combination of meteorological and magnetic measurements also had a strong tradition in central Europe with the most outstanding example of the Societas Meteorologica Palatina-a network of stations for meteorological observations (Kington 1974). It was founded in 1780 and under the leadership of Johann Hemmer declination measurements were performed at up to 19 stations spread over Europe (Fig. 6). All stations had to follow instructions to ensure consistent measurements at the different stations. Observers should be aware of iron, natural and artificial magnets and magnetic 


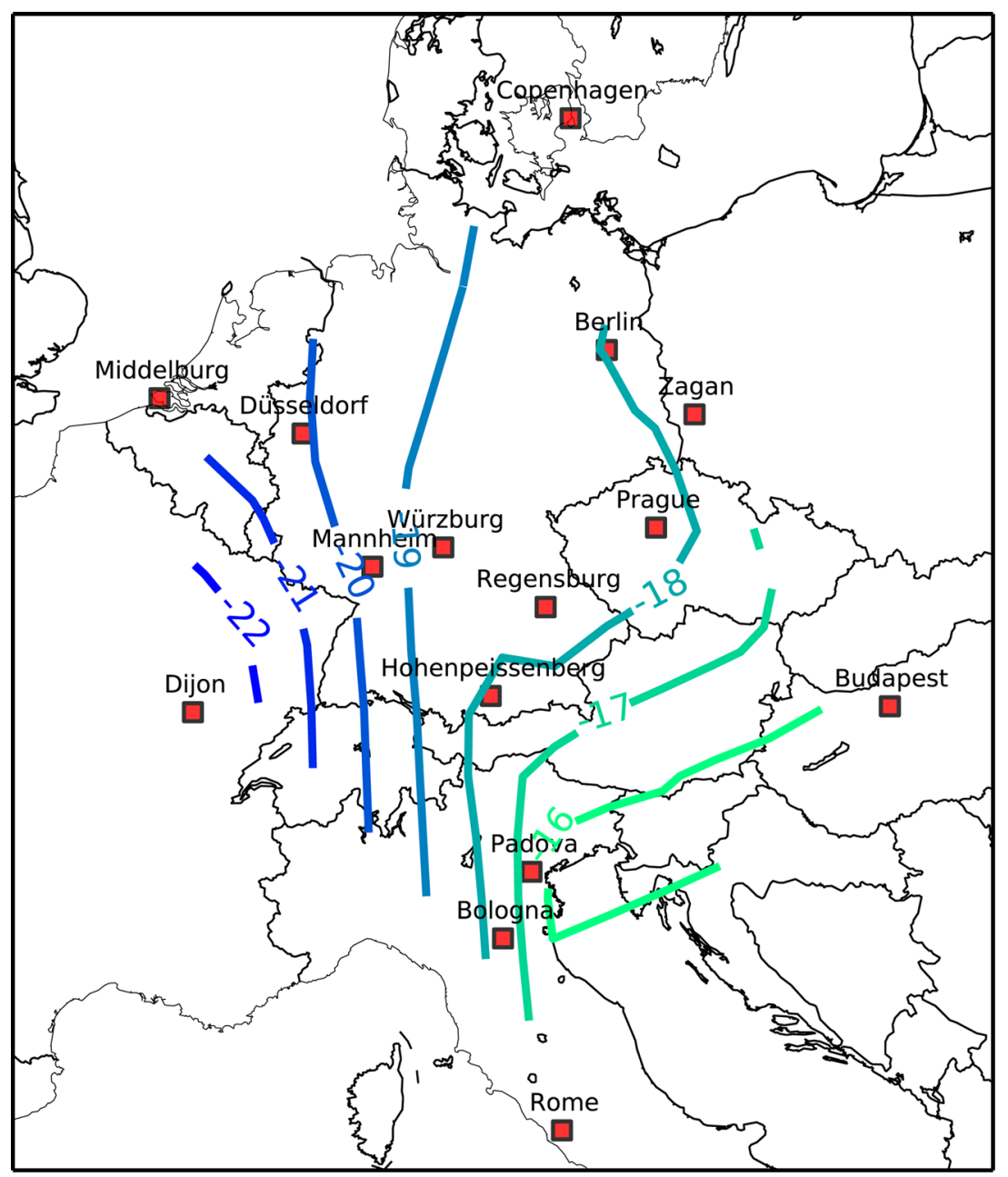

Figure 6. Isogonic chart calculated from annual means at the stations of the Societas Meteorologica Palatina (red squares presented on a modern map) for the year 1784 (Hemmer 1786).

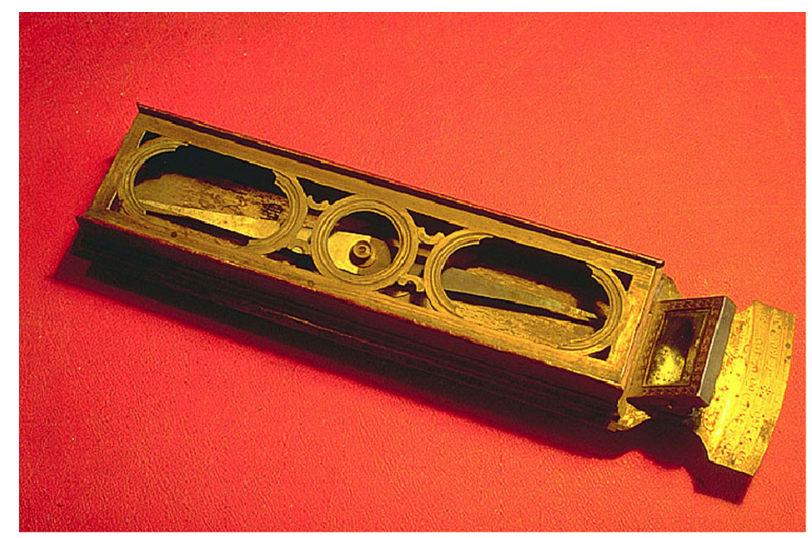

Figure 7. Declinatorium by Georg Freidrich Brander and Höschel (Universita di Bologna, Dipartimento di Astronomia, MUSEO DELLA SPECOLA).

declination measurements were usually performed three times a day and annually published in the 'Ephemerides' (e.g. Hemmer 1783). We investigated the 'Ephemerides' and collected declination values for the period 1781-1792. Another important aspect is that the stations were supplied with the same instruments - a declinatorium by Georg Friedrich Brander (Fig. 7). A detailed description of the declinatorium can be found at Brander (1779) and its resolution is discussed in Section 4.1 .
The instruments by Brander were also used in several monasteries, which were places of rich scientific tradition during that time. Korte et al. (2009) already investigated measurements at monasteries in Kremsmünster, Augsburg (St. Stephan) and Hohenpeissenberg. For the latter location measurements were initiated by the Societas Meteorologica Palatina. We have inspected meteorological yearbooks of the monastery Kremsmünster to extend the collection as well as to add more valuable meta information to the database. In the yearbooks, declination measurements were registered since 1815. In the early years, the number of observations per year fluctuated and the series was even interrupted from 1826 until 1828. From 1829 on, the number continuously increased, and since 1834 measurements were performed in the beginning and end of each month twice a day. The last record in the yearbooks originates from 1842 December 31 . In the yearbook of 1841, a correction of $32^{\prime}$ is mentioned for declination values derived with the Brander declinatorium after comparing this instrument with the Gaussian magnetometer. This correction was applied in the final table of the yearbook 1841 until June, when measurements started to be regularly performed with the Gaussian magnetometer. Reslhuber (1854) summarized the time-series extracted from the yearbooks now using a correction factor of $44^{\prime}$ for declination values determined with the Brander declinatorium. However, between 1841 June 1841 and 1842 May still a difference of 9' (of unknown origin) between yearbook records and Reslhuber's results was detected. In the database both 


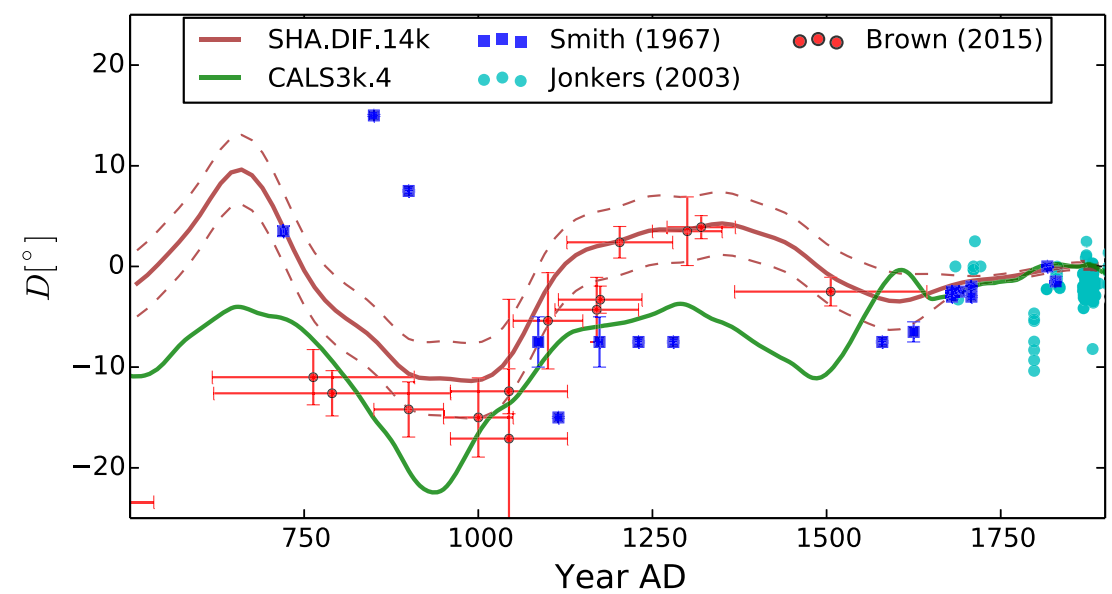

Figure 8. Temporal evolution of $D$ in China depicted by historical records (Smith \& Needham 1967; Jonkers et al. 2003), archaeomagnetic data (Brown et al. 2015a) as well as CALS3k.4 (Korte \& Constable 2011) and SHA.DIF.14k (Pavón-Carrasco et al. 2014) models. Models were evaluated at $110^{\circ} \mathrm{E}$ and $35^{\circ} \mathrm{N}$ and records lie within a $1000 \mathrm{~km}$ radius.

time-series are provided with an account for their difference in the comment field. More reports (Reslhuber 1856, 1859, 1860a, 1861) provide regular measurements of all three geomagnetic components until 1856 in Kremsmünster.

The measurements in the monastery Kremsmünster already coincide with efforts to systematically determine the global geomagnetic field. The monastery was part of the 'Göttingen Magnetic Union' guided by Gauss and Weber (e.g. Chapman \& Bartels 1962). Furthermore, there was a strong cooperation with Karl Kreil, the first director of the 'k.k. Centralanstalt für Meteorologie und Erdmagnetismus' (today ZAMG), which was founded in 1851. Kreil performed a comprehensive measurement campaign in the AustroHungarian Empire including the Adriatic coast as well as in southeast Europe and parts of Asia from 1843 to 1858 (e.g. Kreil 1862). We have collected the original geomagnetic values, because the compilation by Jonkers et al. (2003) contains the values reduced to the epoch of 1850 . Diurnal corrections are not considered for the original values. We assume, however, that for the large investigated region and period the reduction error-reduction was based on observatory values from Vienna and Prague, respectively-is greater than the diurnal/annual variation. For the second land survey at the end of the 19th century in Austria (Liznar 1895) and Hungary (Kurländer 1896) reduced values have been integrated in the database due to the smaller spatial and temporal extent (18891893 and 1892-1894, respectively) of the campaign. During the 19th century, the Imperial and Royal Navy carried out several magnetic surveys in the Adriatic Sea for scientific purposes. Schellander (1871) collected all records of this region since 1806 and was responsible for the survey from 1867 to 1870 . Further surveys were conducted by Laschober (1892) in 1889 and 1890 and by Kesslitz (1907). Finally, a time-series for Vienna from 1851 until 1898 (Toperczer 1952) was integrated in the database.

Beside the detailed study of the scientific development of geomagnetism in central Europe, we were able to integrate a few historical records from other continents into the database. For instance, Vaquero \& Trigo (2005) summarized declination observations in Rio de Janeiro by Bento Sanches Dorta from 1781 to 1788 . Smith \& Needham (1967) compiled 18 declination observations from China covering a period from 720 to 1829 AD (Fig. 8). This data set contains therewith the earliest direct observations of the geomagnetic field. While for the oldest record - observed by I-Hsing - the original manuscript could not be found, Smith \& Needham (1967) could at least trace it back to documents from 1713, which increases the credibility of this datum. For other early observations, the dating uncertainty is not well specified. Nevertheless, collected values since around the year $1100 \mathrm{AD}$ show quite good agreement (Fig. 8) with archaeomagnetic data (Brown et al. 2015a) and geomagnetic field models (Korte \& Constable 2011; Pavón-Carrasco et al. 2014). For the modern era, consistency with historical records by Jonkers et al. (2003) is strong. Therefore, we consider this set as 'basically useful'. Furthermore, declination values derived from 15 th century portolan charts (Cafarella et al. 1992; Yilmaz et al. 2010) are included in the database.

\subsection{Archaeomagnetic and volcanic records}

\subsubsection{Published collections}

The majority of archaeomagnetic and volcanic records covering the last $50000 \mathrm{yr}$ has been directly integrated from GEOMAGIA50.v3 database, which is described in detail by Brown et al. (2015a). Minor modifications of field names are reported in the HISTMAG manual (Supplementary Materials A). The comp_id ' GX' identifies the different records from GEOMAGIA50.v3, where X stands for the UID used by Brown et al. (2015a). Additionally, uncertainties for directional components of indirect measurements (ddecl,dinc) were calculated with formulae by Piper (1989):

ddecl $=\frac{81 \alpha_{95}}{140 \cos I}, \quad$ dinc $=\frac{81 \alpha_{95}}{140}$,

using $\alpha_{95}$ and inclination $I$, when available. In the case of missing inclination information, no ddecl values have been calculated. Uncertainties of archaeo- and palaeointensities (dinten) are directly taken over, whereby calculation methods can differ (e.g. one or two standard deviations or standard error) for different records (see Brown et al. 2015a).

\subsubsection{This study}

The purpose of HISTMAG database is not the collection of newly published archaeomagnetic or volcanic data. Accordingly new entries of indirect observations are very limited and were restricted mainly to the new data of one of the authors (ES). The database was supplied with published directional data (33), some accompanied 
by intensity (2), from 12 locations in Germany and Austria (Klemm et al. 2007; Schnepp 2011a,b; Schnepp et al. 2015, 2016; Schnepp \& Brüggler 2016; Schnepp 2016, 2017). In addition, it was decided to include one further study from Poland, which is close to Austria $(<1000 \mathrm{~km})$ and poorly covered with indirect data. The data set (Czyszek \& Czyszek 1987) was published long time ago and contains 19 inclinations, 12 intensities and 36 intensities with inclinations obtained from displaced material (bricks and whorls) using the Thellier method. The ages range from $3000 \mathrm{BC}$ to $1925 \mathrm{AD}$, but most are medieval or modern. Furthermore, 50 old data have been supplied with stratigraphic information, which is very useful for Bayesian modelling (e.g. Schnepp et al. 2004). Each record is assigned a unique $s e q$ number composed of a country acronym (ISO-2), a number defining the site and location and a number identifying the stratigraphic position counted from top downwards. For example, seq number 'DE_035_02' is used for the record of the second layer down within the bread oven floor sequence in Lübeck, Germany (Schnepp et al. 2009). Fields prev and next define adjacent under- ('DE_035_03') and overlying ('DE_035_01') records, respectively. Data from the same stratum are defined by the equal field.

In the course of these works, some data were corrected or revised using the newest information. One direction and one age of the German data set has been revised (Schnepp 2008, 2010), while in 11 cases for Germany and one for Austria entries inherited from GEOMAGIA50.v3 (Brown et al. 2015a) have been changed because they disagreed with the author's database. This concerned a longitude, a country name, two precision parameters, four ages and seven location names, while one direction of a displaced structure was flagged as unreliable. One entry was flagged as duplicate, because the location Drassburg (Darufalva) in Austria appears also with its Hungarian name and rounded site coordinates as a Hungarian location in GEOMAGIA50.v3. Apart from Austrian and German records, three wrong pubID values from France (Hervé et al. 2011) and four wrong country names in the study by Sternberg (1989) were detected and corrected. Finally, wrong longitude signs for 62 records from Spain and Portugal were adjusted. All these corrections made for HISTMAG were also communicated to Maxwell Brown, who is the custodian of GEOMAGIA50.v3.

\subsection{Duplicates}

In Section 3.1.2, we occasionally stressed out that historical records, which we have investigated, have already been collected by other authors (Jonkers et al. 2003; Korte et al. 2009). We deal with this partial redundancy in a way that we flag concerned records from former publications as duplicates. This decision was made due to the fact that we added more metadata to our collections and, therefore, records can be scrutinized more thoroughly. The corresponding duplicates, however, are kept in the database to provide full traceability of the contents. Please keep in mind that we only defined duplicates, when (1) we acquired the respective record and (2) a convincing agreement between the record and its counterpart regarding location, time, measurement value and/or reference could be found. That is, we did not search for internal duplicates within the data sets provided by Jonkers et al. (2003), especially, as we do not have access to all references. In several cases, it would be impossible to decide whether two records are the same or just by chance temporally and spatially close but different records. In total, we found 471 historical duplicates.

Beside the one duplicate record detected in GEOMAGIA50.v3 database itself (Section 3.2.2), it was decided to flag the original
83 indirect records, which required a correction or revision, as duplicates in HISTMAG database. Revised/corrected versions were added as new entries for easier handling of future updates and revisions of GEOMAGIA50.v3 database.

\section{QUALITY OF HISTORICAL RECORDS}

The quality of historical records is driven on the one hand by random measurement errors and, on the other hand, by systematic bias introduced by the source of the record. Besides instrumental uncertainties, measurement errors can originate from artificial or natural magnetic disturbances (e.g. crustal anomalies or ionospheric disturbances). While in the early years, observational errors exceeded the magnitude of regular daily variations of the external field (Alexandrescu et al. 1996), these effects were covered by measurements conducted several times a day at least from the end of the 18th century (e.g. Hemmer 1783). Irregular field variations-for example, magnetic storms, first discovered by Celsius and Graham in 1741 (Chapman \& Bartels 1962) - were documented during the 18th (e.g. Hansen \& Aspaas 2005) and the 19th century (Reslhuber 1860b). Before that time, the effect of these disturbances is hard to assess. However, the effect of these disturbances can be expected to be significantly reduced, because many historical records in the database represent means of several observations.

General estimates of instrumental and observational uncertainties have been made by different authors. For example, Cafarella et al. (1992) reported uncertainties of $5^{\circ}-6^{\circ}$ related to the scale division of the compass card (into 'quarters' with $11.25^{\circ}$ width) during Colombo's time. Jackson et al. (2000) have used repeated declination measurements performed on one day to estimate an error of $\approx 0.5^{\circ}$ from the standard deviation for pre-19th century data. Alexandrescu et al. (1996) estimated an accuracy of better than $10^{\prime}$ for late 18 th century declination measurements in Paris. Inclination determinations were generally affected by higher inaccuracies (Chapman \& Bartels 1962). Brander (1779) reported large errors caused by the inaccurate magnetization of magnetic needles. He gave an example where the inclination value changed for more than $3^{\circ}$ when the needle was suspended in opposed direction. However, from the middle of the 19th century on, inclination measurements were continuously improved with inventions of the 'dipping needle deflector', the induction-inclinometer and the Earth inductor (Multhauf \& Good 1987). As far as the absolute intensity determinations (Gauss 1833) are concerned, their uncertainty can be estimated (e.g. Bock 1945) from mechanics of used magnetic theodolites (e.g. from deflection angle readings, magnet temperature correction, oscillation damping and torsion correction).

The source of the magnetic measurement can significantly contribute to its uncertainty. For several groups - such as sundials and historical maps-larger errors can be assumed (e.g. Korte et al. 2009). Therefore, we split uncertainty investigations in two parts. In Section 4.1, we use collected metadata regarding instruments and measurement procedures to quantify statistical errors. Furthermore, additional information extracted from original documents or summarizing articles is discussed and its handling in the database is presented. In Section 4.2, the potential bias of data sets with suspicious credibility is investigated.

\subsection{Measurement uncertainties}

The information on the used instrument (e.g. Fig. 7) is a valuable tool to quantify statistical measurement errors as for the succeeding 
examples. Reslhuber (1854) gives a reading accuracy of $2^{\prime}-3^{\prime}$ for the Brander declinatorium for a scale division of $5^{\prime}$. During his expedition to Norway, Hell used the Kratzstein declinometer for several measurements, for which a reading accuracy of 2 ' could be reached using a convex glass (Hansen \& Aspaas 2005). During 1770s in Freiberg, declination measurements were performed with two different instruments. The used surveyor compass, the common device for measuring the orientation of mining adits at that time, allowed the reading of $1 / 64 \mathrm{hr}\left(1 \mathrm{hr}=15^{\circ}\right)$, which corresponds to an uncertainty of $\sim 7^{\prime}$. The second device-equipped with a 6 inch needlehad a scale division of $1 / 8^{\circ}$ delivering an uncertainty of $\sim 4^{\prime}$. For declination values retrospectively derived from adit directions, we calculated mean values from all directions within one mining area and the associated standard deviation can be seen as a measure for their uncertainties. Moreover, the length of the needle provides the possibility to define the reading accuracy. Bartha (2003) estimated a reading error of $15^{\prime}$ assuming a reading accuracy of $1 \mathrm{~mm}$ for the needle length of $45 \mathrm{~cm}$ used by Marsigli (1696). In other cases, we have to count on the assessment of authors, who processed the historical data. Schellander (1871) estimated an accuracy of about $6^{\prime}-10^{\prime}$ for declination measurements at the Adriatic coasts by Marieni in the beginning of the 19th century. Vaquero \& Trigo (2005) considered an error of $10^{\prime}$ as appropriate for Sanches Dorta's observations in Rio. As in case of the Chinese data set (Smith \& Needham 1967), the measurement error was deviated from the statement describing the record. In this way, the text ' $3-4 \mathrm{E}^{\circ}$ ' was transferred to a declination value of $+3.5^{\circ}$ with an uncertainty of $0.5^{\circ}$. The abovepresented uncertainty estimates are given in the database in the field ddecl for the corresponding records. These single measurement uncertainties were also applied to related mean values (e.g. monthly or annual). In this case, the $d d e c l$ value represents a conservative estimate.

The 'technical' uncertainty information has to be complemented with possible inconsistencies or incidents during the measurements. These have been taken from the original documents and are described in the comment field in the database. We have chosen a text format instead of, for example, a unique code, as the variety of possible incidents is by far too large. For instance, the uncertainty of location or age for some Chinese records (Smith \& Needham 1967), which cannot be quantified, are documented in the comment field. We mention differences revealed by comparison measurements with different instruments (e.g. Reslhuber 1854) or baseline jumps (e.g. Hemmer 1788). Furthermore, it is noted, when authors suggest a correction of records due to sudden changes during the measurement series, as for example, Vaquero \& Trigo (2005). Corrections due to the influence of iron objects as well as recognized magnetic storms as in case of Maximilian Hell's measurements in Vardø (Hansen \& Aspaas 2005) are also documented in the comment field. After realizing the disturbing effect of the oven and the quadrant, Hell started a new time-series in a new observatory. However, first (1769 April 26-May 19) and second time-series (1769 May 23June 20) both yield the same mean value and diurnal variations are comparable to modern observations for these latitudes (Hansen \& Aspaas 2005), which guarantees the overall quality of these records. Only in extreme cases, records were flagged as unreliable depending on the original information. This is the case, for example, for the two inclination measurements in 1817 in Kremsmünster, which are overestimated due to imperfections of instrument and method (Reslhuber 1854). Furthermore, records without reliable dating (e.g. Stevin 1599; Kircher 1654; Wright 1657, see Section 3.1.1) fall into this category.

\subsection{Systematic bias}

The above-defined approach for the assessment of data quality is hampered, if certain data sets are biased in a way that cannot be extracted from original documents. HISTMAG database provides the possibility to test specific historical data sets against other temporally and spatially surrounding records. We adopt the strategy of Arneitz et al. (2017), who investigated the reliability of archaeomagnetic and palaeomagnetic records via comparison with historical data. Here, instead of indirect records, mining data (derived from adit directions and mining maps), historical maps and sundials are compared with all other remaining historical records. Details on the evaluation with corresponding figures can be found in Supplementary Materials B.

In a first evaluation run, it turned out that assumed uncertainties of historical declination measurements $\left(0.5^{\circ}\right)$ — used for Monte Carlo simulations - are underestimated for the specific data sets. Therefore, a posteriori estimates of individual uncertainties $\left(\tilde{\epsilon}_{D}\right)$ were determined and have been used in a second run. The inspection of time-series derived from sundials revealed three obvious outliers for Nürnberg (one record) and Augsburg (two records), which were excluded from the evaluation (red crosses in Fig. 3). The a posteriori error estimates $\tilde{\epsilon}_{D}$ largely exceed $0.5^{\circ}$, reaching up to $\approx 8^{\circ}$ in the case of historical maps. Systematic deviations from the remaining historical records were determined for all three data sets (Table 2).

Historical maps have the largest offset $\left(\mu_{D}=+2.7^{\circ}\right)$. Compass roses on these maps could have been placed for decorative purposes only. Moreover, systematic positive (Eastern) declination offsets $\left(\mu_{D}=+2.7^{\circ}\right)$ can be explained by the hypothesis that many compass roses were copied from older maps during times when declination was monotonously decreasing in central Europe (Fig. 3). The small number of maps reporting explicit declination values does not support reliable conclusions; however, they seem to provide more reliable results $\left(\mu_{D}=+0.9^{\circ}\right)$.

Declination records derived from mining adit directions and mining maps show a smaller bias $\left(\mu_{D}=+1.1^{\circ}\right)$, whereby the major contribution comes from the former subset $\left(\mu_{D}=+1.4^{\circ}\right)$. Magnetic anomalies in the mining areas could affect compass measurements, even though surveyors were reported to be aware of this effect (Schreyer 1886). Declination values noted on mining maps, on the contrary, do not show a systematic offset $\left(\mu_{D}=+0.4^{\circ}\right)$.

The sundial data set has a negative (Western) offset $\left(\mu_{D}=-0.9^{\circ}\right)$. Therefore, a possible explanation like the copying of older declination values as in case for historical maps can be ruled out. Sundials from Augsburg (after outlier rejection) do not yield a systematic offset $\left(\mu_{D}=+0.1^{\circ}\right)$. Generally, it has to be noted that the results have to be interpreted with caution because investigated data sets may have strong internal correlations, for example, due to geographical distribution, decreasing the effective sample size $N_{D}$ and statistical testing capabilities. Therefore, the cancellation of different effects, as observed by Arneitz et al. (2017) for diverse indirect data sets, may not be ensured in this case.

Finally, the data sets of portolan charts and Chinese records (Smith \& Needham 1967) were also evaluated (Table 2). However, the small sample size does not support meaningful a posteriori measurement error estimates, nor it is possible to draw significant conclusions. It has to be noted that from the Chinese data sets only records younger than $1500 \mathrm{AD}$ could be evaluated. They show good agreement with other historical records $\left(\mu_{D}=-0.6^{\circ}\right)$ as expected from inspection of Fig. 8. 
Table 2. Analysis of specific historical data sets. $\mu_{D}$ is the weighted mean difference between investigated records and remaining historical measurements. $S_{D}$ is an estimate of the standard error of $\mu_{D}$ caused by random measurement errors (determined with Monte Carlo simulations of synthetic records), $N_{D}$ is the effective sample size supporting $\mu_{D}$ and $S_{D}$, based on $n$ selected records out of a total of $n_{\text {tot }}$ investigated records. Selected records do not exceed a given error threshold. Column conf. level provides the maximum confidence level for rejecting the null hypothesis $\mu_{D}-\mu_{D, 0}=0$ of a Student's $t$-test. $\mu_{D, 0}$ is obtained by replacing actual records with values from the CALS3k.4 model (Korte \& Constable 2011). Rejection can be considered equivalent to existence of a significant bias of the data set with respect to other historical measurements. $\tilde{\epsilon}_{D}$ represents an estimate for the uncertainty of individual records (see Arneitz et al. (2017) for more details). Outliers were rejected in the evaluation for data sets marked with * (see Fig. 3). Supporting figures can be found in Supplementary Materials B.

\begin{tabular}{|c|c|c|c|c|c|c|}
\hline Data set & $\mu_{D}\left(^{\circ}\right)$ & $S_{D}\left({ }^{\circ}\right)$ & $N_{D}$ & $n\left(n_{\text {tot }}\right)$ & Conf. level (per cent) & $\tilde{\epsilon}_{D}\left({ }^{\circ}\right)$ \\
\hline Mining & +1.1 & 0.3 & 38 & $62(90)$ & 99.0 & 1.6 \\
\hline Adit direction & +1.4 & 0.3 & 28 & $42(60)$ & 99.0 & \\
\hline Maps & +0.4 & 0.5 & 10 & $20(30)$ & 80.0 & \\
\hline Maps & +2.7 & 1.3 & 34 & $69(71)$ & 99.0 & 8.1 \\
\hline Compass rose & +2.9 & 1.3 & 33 & $66(67)$ & 99.0 & \\
\hline Written & +0.9 & 6.5 & 1 & $3(4)$ & - & \\
\hline Sundials* & -0.9 & 0.6 & 48 & $104(139)$ & 99.0 & 4.3 \\
\hline Augsburg* & +0.1 & 1.0 & 18 & $21(29)$ & $<50$ & \\
\hline Nürnberg* & -0.9 & 0.8 & 31 & $67(74)$ & 99.0 & \\
\hline Portolan charts & +2.0 & 0.7 & 4 & $5(11)$ & - & - \\
\hline Smith \& Needham (1967) & -0.6 & 0.3 & 4 & $6(9)$ & - & - \\
\hline
\end{tabular}

\section{CONCLUSIONS}

HISTMAG is an online accessible database that combines historical, archaeomagnetic and volcanic records of past geomagnetic field variations. The major contributions to the data collection come from the compilation by Jonkers et al. (2003) and GEOMAGIA50v.3 database (Brown et al. 2015a), respectively, from which the general structure of HISTMAG was adopted. These data are complemented by newly acquired historical and archaeomagnetic records from central Europe. In the course of new data acquisition, the database was complemented by several new fields, which allow for a detailed description of the different data sets. The establishment of HISTMAG database is a further step towards a better understanding of the geomagnetic past, and supports more detailed studies on the reliability and quality of geomagnetic records. For example, a data comparison strategy revealed strong scatter and a systematic offset for declination values derived from compass roses on historical maps with respect to other historical records. The user-comment function is intended for scientific discussion, which will reveal more (not yet captured) information on the different records and, therefore, can be used for reliability and uncertainty assessments in future database updates. Finally, the data collection serves as the basis for future geomagnetic field modelling approaches.

The addition of new historical records, and reliability evaluation of these data is the main focus of our future work. There is a variety of new potential sources (e.g. astrolabes or globes), which could not be examined within the framework of this study. We would be grateful for any related ideas and suggestions as well as indications of not yet incorporated publications. Furthermore, users are invited to provide new records (with corresponding metadata), which can be added in the course of future revisions of the database.

\section{ACKNOWLEDGEMENTS}

The research is funded by Austrian Science Fund (FWF): P24722N19. The archaeomagnetic study was funded by the Austrian Science Fund (FWF): P23295_N21. The manuscript was improved by the constructive comments of Harald Böhnel and one anonymous reviewer. The authors wish to thank P. Amand Kraml (Sternwarte Kremsmünster), Mr Ehmayer (Österreichisches Staatsarchiv), Robert Holnsteiner (Bundesministerium für Wirtschaft, Forschung und Wissenschaft, Sektion III Energie und Bergbau), Andrea Draxler, Marie Kröhl, Maria Nievoll and Yvonne Fleischhacker.

\section{REFERENCES}

Alexandrescu, M., Courtillot, V. \& Le Mouël, J.-L., 1996. Geomagnetic field direction in Paris since the mid-sixteenth century, Phys. Earth planet. Inter, 98(3), 321-360.

Arneitz, P., Egli, R. \& Leonhardt, R., 2017. Unbiased analysis of geomagnetic data sets and comparison of historical data with paleomagnetic and archeomagnetic records, Rev. Geophys., 55(1), 5-39.

Balás, P., 1850. Zusammenstellung derjenigen Data, die aus Veranlassung der magnetischen Declinations Beobachtungen des K. K. Bergrathes und Professors Christian Doppler, durch den K. K. Oberbieberstollner, Markscheids Adjuncten Paul Balás gesammelt wurden, Windschacht, 11 Juni 1850, vol. ŠÚBA MÚ 402, Slovenský banský archív v Banskej Štiavnici, Complemented by other author with observations made at Windschacht between 1851-1871.

Balmer, H., 1956. Beiträge zur Geschichte der Erkenntnis des Erdmagnetismus, H.R. Sauerländer, Aarau.

Bartha, L., 2003. Halley, Marsigli és az első mágneses felmérés a Kárpátmedencében (Halley, Marsigli and the first magnetic measurement in the Carpathian Basin), M. Geofiz., 44, 143-148.

Bock, R.E., 1945. Praxis der magnetischen Messungen, Gebrüder Borntraeger, Berlin-Zehlendorf, Edwards Brothers, Inc., Ann Arbor, Michigan, USA.

Brander, G.F., 1779. Beschreibung eines magnetischen Declinatorii und Inclinatorii, Klett und Franck, Augsburg. Available at: http://www.e-rara.ch/zut/content/titleinfo/854229, last accessed June 2017.

Brown, M., Donadini, F., Korte, M., Nilsson, A., Korhonen, K., Lodge, A., Lengyel, S. \& Constable, C., 2015a. GEOMAGIA50.v3: 1. general structure and modifications to the archeological and volcanic database, Earth Planets Space, 67(1), 83, doi:10.1186/s40623-015-0232-0.

Brown, M.C. et al., 2015b. GEOMAGIA50.v3: 2. a new paleomagnetic database for lake and marine sediments, Earth Planets Space, 67(1), 70, doi:10.1186/s40623-015-0233-z.

Cafarella, L., Santis, A.D. \& Meloni, A., 1992. Secular variation in Italy from historical geomagnetic field measurements, Phys. Earth planet. Inter., 73(3), 206-221.

Chapman, S. \& Bartels, J., 1962. Geomagnetism, Oxford Univ. Press. Courtillot, V. \& Le Mouël, J.-L., 2007. The study of Earth's magnetism (1269-1950): a foundation by Peregrinus and subsequent development 
of geomagnetism and paleomagnetism, Rev. Geophys., 45, RG3008, doi:10.1029/2006RG000198.

Czyszek, Z. \& Czyszek, W., 1987. Secular variations of the magnetic field in Poland from archaeomagnetic studies, Acta Geophys. Polonia, 35, 187215.

de Ulloa, A. \& Schwabe, J.J., 1751. Reise nach dem Königreiche Peru, Arkstee und Merkus, Leipzig.

Donadini, F., Korhonen, K., Riisager, P. \& Pesonen, L.J., 2006. Database for Holocene geomagnetic intensity information, EOS, Trans. Am. geophys. Un., 87(14), 137-143.

Doppler, C., 1850. Mittheilungen über ältere magnetische DeclinationsBeobachtungen, samt deren Zustandebringung sich beziehenden Verhandlungen der mathematisch-naturwissenschaftlichen Classe der kaiserlichen Akademie der Wissenschaften, Sitzungsberichte der k. Akadamie der Wissenschaften besonders abgedruckt, Erstes Heft.

Doppler, C., 1851. Ueber die in neuester Zeit in Freiberg in Sachsen aufgefundenen Declinationsbeobachtungen aus älterer Zeit, Sitzb. d. mathem.naturw. Cl., VII(I), 160-162.

Folgheraiter, G., 1899. Sur les variations séculaires de l'inclinaison magnétique dans l'antiquité, J. Phys., 8, 660-667.

Gauss, C.F., 1833. Die Intensität der erdmagnetischen Kraft, zurückgeführt auf absolutes Maass, Annal. Phys., 104(6), 241-273.

Genevey, A., Gallet, Y., Constable, C.G., Korte, M. \& Hulot, G., 2008. ArcheoInt: an upgraded compilation of geomagnetic field intensity data for the past ten millennia and its application to the recovery of the past dipole moment, Geochem. Geophys. Geosyst., 9, Q04038, doi:10.1029/2007GC001881.

Halley, E., 1701. A New and Correct Chart Shewing the Variations of the Compass in the Western \& Southern Oceans as Observed in ye Year 1700 by his Ma. ties Command by Edm. Halley.

Hansen, T.L. \& Aspaas, P.P., 2005. Maximilian Hell's Geomagnetic Observations in Norway 1769, Tromsø Geophysical Observatory, University of Tromsø, Tromsø.

Hemmer, J.J., 1783. Ephemerides Societatis Meteorologicae Palatinae. Historia et Observationes 1781, Schwan, Mannheim.

Hemmer, J.J., 1786. Ephemerides Societatis Meteorologicae Palatinae. Observationes Anni 1784, Fontaine, Mannheim.

Hemmer, J.J., 1788. Ephemerides Societatis Meteorologicae Palatinae. Observationes Anni 1786, Mannheim.

Hervé, G., Schnepp, E., Chauvin, A., Lanos, P. \& Nowaczyk, N., 2011. Archaeomagnetic results on three Early Iron Age salt-kilns from Moyenvic (France), Geophys. J. Int., 185(1), 144-156.

Jackson, A., Jonkers, A.R.T. \& Walker, M.R., 2000. Four centuries of geomagnetic secular variation from historical records, Phil. Trans. R. Soc. Lond., A: Math. Phys. Eng. Sci., 358(1768), 957-990.

Jonkers, A.R.T., Jackson, A. \& Murray, A., 2003. Four centuries of geomagnetic data from historical records, Rev. Geophys., 41, 1006, doi:10.1029/2002RG000115.

Kesslitz, W., 1907. Bestimmungen der magnetischen Deklination im Österreichisch-Ungarischen Küstengebiete, in Erdmagnetische Beobachtungen, Vol. 4, Kommissionsverlag von Gerold \& Komp. In Wien.

Kington, J.A., 1974. The Societas Meteorologica Palatina: an eighteenthcentury meteorological society, Weather, 29(11), 416-426.

Kircher, A., 1654. Magnes sive de Arte Magnetica (Opus Tripartitum), 3rd edn, Mascardi, Rome.

Klemm, S., Nelle, O., Grabner, M., Geihofer, D. \& Schnepp, E., 2007. Interdisziplinäre Untersuchungen von Kohlstätten aus Mittelalter und Neuzeit in der Eisenerzer Ramsau, Steiermark, Archaeol. Austriaca, 89(2005), 269-329.

Koenigsberger, J., 1936. Die Abhängigkeit der natürlichen remanenten Magnetisierung bei Eruptivgesteinen von deren Alter und Zusammensetzung, Beitr. Angew. Geophys, 5, 193-246.

Kono, M., 2007. Geomagnetism in perspective, in Treatise on Geophysics, Vol. 5, chap. 1, pp. 1-31, ed. Schubert, G., Elsevier, Amsterdam.

Korhonen, K., Donadini, F., Riisager, P. \& Pesonen, L., 2008. GEOMAGIA50: an archeointensity database with PHP and MySQL, Geochem. Geophys. Geosyst., 9, Q04029, doi:10.1029/2007GC001893.
Korte, M. \& Constable, C., 2011. Improving geomagnetic field reconstructions for 0-3 ka, Phys. Earth planet. Inter., 188(3-4), 247-259.

Korte, M., Genevey, A., Constable, C.G., Frank, U. \& Schnepp, E., 2005. Continuous geomagnetic field models for the past 7 millennia: 1. A new global data compilation, Geochem. Geophys. Geosyst., 6, Q02H15, doi:10.1029/2004GC000800.

Korte, M., Mandea, M. \& Matzka, J., 2009. A historical declination curve for Munich from different data sources, Phys. Earth planet. Inter., 177(3-4), 161-172.

Kreil, K., 1862. Magnetische und geographische Ortsbestimmungen im südöstlichen Europa und einigen Küstenpunkten Asiens, Denkschriften der Kaiserlichen Akademie der Wissenschaften, 20, 1-94.

Kurländer, I., 1896. Erdmagnetische Messungen in den Länern der Ungarischen Krone in den Jahren 1892-1894 (Földmágnességi mérések a Magyar Korona Országaiban 1892-1894), Kön. Ung. Naturwissenschaftliche Gesellschaft, Budapest.

Laschober, F., 1892. Magnetische Beobachtungen an den Küsten der Adria in den Jahren 1889 und 1890, Verlag des k. und k. Hydrographischen Amtes, Pola, Beilage zu den Mitteilungen aus dem Gebiete des Seewesens.

Lindgren, U., 2013. Die mathematischen und astronomischen Grundlagen von Philipp Appians Bayern-Karte, in Die Vermessung Bayerns, 450 Jahre, Philipp Apians Große Karte, pp. 151-192, Bayerisches Staatsministerium der Finanzen, für Landesentwicklung und Heimat, Abteilung VII, Bayerische Vermessungsverwaltung, Informations- und Kommunikationstechnik, Munich.

Liznar, J., 1895. Die Vertheilung der erdmagnetischen Kraft in ÖsterreichUngarn zur Epoche 1890.0 nach in den Jahren 1889 bis 1894 ausgeführten Messungen, Denkschr. Aka. Wiss. Wien, 62, 137-368.

Ludwig, K.-H. \& Schmidtchen, V., 1997. Metalle und Macht 1000-1600, Propyläen Technikgeschichte, Berlin.

Malin, S. R.C. \& Bullard, E., 1981. The direction of the Earth's Magnetic Field at London, 1570-1975, Phil. Trans. R. Soc. Lond., A: Math. Phys. Eng. Sci., 299(1450), 357-423.

Marsigli, L.F., 1696. Manuscript, Marsigli Collection, Bologna.

Marsigli, L.F., 1700. Danubius Operis Prodromus, Ad Regiam Societytem Anglicam, Norinbergae (Nürnberg).

Mikoviny, S., 1732. Epistola de methodo concinnandarum Mapparum Hungariae, Posonii.

Mikoviny, S., 1735. De mappis suis ad lectorem Monitio, in Notitia Hungariae novae, Vol. I., Viennae, Mathias Bel.

Müller, J.H., Michaelles, J. \& Spies, J.A., 1723. Observationes astronomicophysicae selectae, in specula Altdorfina ab anno novae eius instaurationis 1711. usque ad praesentem annum academiae secularem 1723 habitae; Pars prior, Kohles, Altdorfium.

Multhauf, R.P. \& Good, G., 1987. A Brief History of Geomagnetism and a Catalog of the Collections of the National Museum of American History, Smithsonian Institution Press.

Needham, J., 1962. Science and Civilisation in China: Volume 4, Physics and Physical Technology, Part 1, Physics, Cambridge Univ. Press.

Paterson, G.A., Tauxe, L., Biggin, A.J., Shaar, R. \& Jonestrask, L.C., 2014. On improving the selection of Thellier-type paleointensity data, Geochem. Geophys. Geosyst., 15(4), 1180-1192.

Pavón-Carrasco, F.J., Osete, M.L., Torta, J.M. \& Santis, A.D., 2014. A geomagnetic field model for the Holocene based on archaeomagnetic and lava flow data, Earth planet. Sci. Lett., 388, 98-109.

Piper, J.D.A., 1989. Palaeomagnetism, in Geomagnetism, Vol. 3, pp. 31-161, Academic, London.

Reslhuber, A., 1854. Ueber das Magnetische Observatorium in Kremsmuenster und die vom Jahre 1839-50 aus den Beobachtungen abgeleiteten Resultate, k.k. Hof-Staatsdruckerei, Wien.

Reslhuber, A., 1856. Magnetische Beobachtungen zu Kremsmuenster in den Jahren 1851, 1852, 1853. Mit einem Nachtrag von F. Lukas, Jahrbuecher der Centralanstalt f. Meteorologie u. Erdmagnetismus, Jahrgang 1853, $33-82$.

Reslhuber, A., 1859. Magnetische Beobachtungen zu Kremsmuenster im Jahre 1854, Jahrbuecher der Centralanstalt f. Meteorologie u. Erdmagnetismus, Jahrgang 1854, 29-42. 
Reslhuber, A., 1860a. Magnetische Beobachtungen zu Kremsmuenster im Jahre 1855. Mit einem Nachtrag von F. Lukas, Jahrbuecher der Centralanstaltf. Meteorologie u. Erdmagnetismus, Jahrgang 1855, 31-44.

Reslhuber, A., 1860b. Bericht ueber die im Jahre 1859 auf dem magnetischen Observatorium zu Kremsmuenster beobachteten Stoerungen, Sitzungsberichte der k.k. Akadamie der Wissenschaften in Wien, 42, 533-572.

Reslhuber, A., 1861. Magnetische Beobachtungen zu Kremsmuenster im Jahre 1856. Mit einem Nachtrag von F. Lukas, Jahrbuecher der Centralanstalt f. Meteorologie u. Erdmagnetismus, Jahrgang 1856, 31-46.

Sabine, E., 1838. Report on the Variations of the Magnetic Intensity Observed at Different Points of the Earth's Surface, Richard and John E. Taylor, London.

Sabine, E., 1872. Contributions to Terrestrial Magnetism. No. XIII, Phil. Trans. R. Soc. Lond., 162, 353-433.

Schellander, J., 1871. Magnetische Beobachtungen an den Küsten des adriatischen Meeres, Jahrbücher der $k$. $k$. Centralanstalt fü Meteorologie und Erdmagnetismus, VI., Jahrgang 1869, 206-229.

Schnepp, E., 2008. Archäomagnetische Altersbestimmung der Kalkbrennöfen HaK 46 und 47, in Archäologie auf Waldeshöhen. Eisenzeit, Mittelalter und Neuzeit auf der 'Kalteiche' bei Haiger, LahnDill-Kreis, pp. 133-136, ed. Verse, F., Münstersche Beiträge zur Urund Frühgeschichtlichen Archäologie 4, Verlag Marie Leidorf, GmbH, Rahden/Westf.

Schnepp, E., 2010. Archäomagnetische Datierung der Öfen auf der Grabung Damsdorf, in Archäologische Studien zum Dorf der Ostsiedlungszeit. Die Wüstungen Miltendorf und Damsdorf in Brandenburg und das ländliche Siedlungswesen des 12. bis 15. Jahrhunderts in Ostmitteleuropa, pp. 414-419, ed. Biermann, F., Forschungen zur Archäologie im Land Brandenburg 12, Brandenburgisches Landesamt für Denkmalpflege und Archäologisches Landesmuseum, Wünsdorf.

Schnepp, E., 2011a. Archäo-, Paläo- und Umweltmagnetik, in Umweltarchäologie-Naturkatastrophen und Umweltwandel im archäologischen Befund. 3. Mitteldeutscher Archäologentag vom 07. bis 09. Oktober 2010 in Halle (Saale), pp. 57-69, eds Bork, H.-R., Meller, H. \& Gerlach, R., Tagungen des Landesmuseum für Vorgeschichte Halle, 6, Landesamt für Denkmalpflege und Archäologie Sachsen-Anhalt, Halle (Saale).

Schnepp, E., 2011b. Archäomagnetische Datierungen an Grabungsbefunden, in Die Karnburg. Forschungen zu Kärntens Königspfalz 2006-2010, pp. 114-120, eds Dolenz, H. \& Baur, C., Kärntner Museumsschriften 81, Verlag des Landesmuseums Kärnten, Klagenfurt.

Schnepp, E., 2016. Archäomagnetische Datierung von Befunden am 'Kleinen Schmidtskopf' bei Elbingerode, Lkr. Harz, in Jahresschrift für Mitteldeutsche Vorgeschichte, 95, pp. 243-250, ed. Meller, H., Landesamt für Denkmalpflege und Archäologie Sachsen-Anhalt, Halle(Saale).

Schnepp, E., 2017. Archäomagnetische Datierungen auf der Grabung Semlach/Eisner bei Knappenberg (Kärnten), in Die Produktion von Ferrum Noricum am Hüttenberger Erzberg. Die Ergebnisse der interdisziplinären Forschungen auf der FundstellenSemlach/Eisner in den Jahren 20062010, pp. 117-130, ed. Cech, B., Austria Antiqua 6, Selbstverlag der Österreichischen Gesellschaft für Archäologie, Wien (im Druck).

Schnepp, E. \& Brüggler, M., 2016. Archaeomagnetic investigation of a Roman glass workshop in Goch-Asperden, Germany, J. Archaeol. Sci.: Rep., 10, 322-330.

Schnepp, E., Pucher, R., Reinders, J., Hambach, U., Soffel, H. \& Hedley, I., 2004. A German catalogue of archaeomagnetic data, Geophys. J. Int., 157(1), 64-78.
Schnepp, E., Lanos, P. \& Chauvin, A., 2009. Geomagnetic paleointensity between 1300 and 1750 A.D. derived from a bread oven floor sequence in Lübeck, Germany, Geochem. Geophys. Geosyst., 10, Q08003, doi:10.1029/2009GC002470.

Schnepp, E., Obenaus, M. \& Lanos, P., 2015. Posterior archaeomagnetic dating: an example from the Early Medieval site Thunau am Kamp, Austria, J. Archaeol. Sci.: Rep., 2, 688-698.

Schnepp, E., Leonhardt, R., Korte, M. \& Klett-Drechsel, J., 2016. Validity of archaeomagnetic field recording: an experimental pottery kiln at Coppengrave, Germany, Geophys. J. Int., 205(1), 622-635.

Schreyer, O., 1886. Erdmagnetische Beobachtungen im Königreich Sachsen, Gerlachsche Buchdruckerei, Freiberg.

Smith, P.J. \& Needham, J., 1967. Magnetic declination in Mediaeval China, Nature, 214, 1213-1214.

Steiner, L., 1923. A Föld mágneses jelenségei, Budapest.

Sternberg, R.S., 1989. Secular variation of archaeomagnetic direction in the American Southwest, AD 750-1425, J. geophys. Res., 94(B1), $527-546$.

Stevin, S., 1599. De Havenvinding, Plantijn, Leyden, Netherlands.

Thellier, E. \& Thellier, O., 1959. Sur l'intensité du champ magnétique terrestre dans le passé historique et géologique, Ann. Géophys., 15, 285237.

Toperczer, M., 1952. Der Verlauf der erdmagnetische Elemente in Wien, 1851 bis 1950, Springer-Verlag, Wien, Sonderabdruck aus Archiv für Meteorologie, Geophysik und Bioklimatologie, Serie A: Meteorologie und Geophysik, Band V, 2.Heft.

Vaquero, J.M. \& Trigo, R.M., 2005. Results of the Rio de Janeiro magnetic observations 1781-1788, Ann. Geophys., 23(5), 1881-1887.

Veinberg, B.P., 1929-1933. Catalogue of Magnetic Determinations in USSR and in Adjacent Countries From 1556 to 1926, Vol. 1-3, Cent. Geophys. Obs., St. Petersburg.

von Humboldt, F.H.A., 1814-1829. Personal Narrative of Travels to the Equinoctial Regions of the New Continent During the Years 1799-1804, by A. de Humboldt and A. Bonpland, Vol. 1-7, Addison-Wesley-Longman, Reading, MA.

Wright, E., 1657. Certaine Errors of Navigation Detected and Corrected, With Many Additions That Were Not in the Former Editions, 3rd edn, Joseph Moxton, London.

Yilmaz, I., Gullu, M., Yilmaz, M. \& Dereli, M.A., 2010. Compass roses on the Book of Navigation (Kitab-1 Bahriye): declination data source for geomagnetic field models, Phys. Earth planet. Inter., 182(3-4), $170-174$.

Zinner, E., 1939. Die ältesten Räderuhren und modernen Sonnenuhren, in Bericht der naturforschenden Gesellschaft, Vol. 28, pp. 1-148, Bamberg.

\section{SUPPORTING INFORMATION}

Supplementary data are available at GJI online.

\section{SupplementaryMaterialsA SupplementaryMaterialsB}

Please note: Oxford University Press is not responsible for the content or functionality of any supporting materials supplied by the authors. Any queries (other than missing material) should be directed to the corresponding author for the paper. 